\title{
Digging behavior in 12 taxa of muroid rodents
}

\author{
DANIEL G. WEBSTER, MYLES H. WILLIAMS, ROGER D. OWENS, \\ VANCE B. GEIGER, and DONALD A. DEWSBURY \\ University of Florida, Gainesville, Florida 32611
}

\begin{abstract}
The digging behavior of 12 taxa of muroid rodents was observed on sand and peat substrates. Overall, significantly more digging was performed on peat than on sand. The percentage of animals of each taxon that dug was found to be positively correlated with both the duration of digging and the number of bouts of digging and negatively correlated with latency to dig. Differences across taxa in the duration of digging were correlated with field observations of the nesting behavior of these taxa; taxa that frequently utilize subterranean nest sites exhibited more digging than those that do not. The motor patterns used in digging are described; Mus musculus was the only species that appeared to exhibit a unique digging pattern. Digging behavior appears to be a pattern that is readily elicited in the laboratory, related to behavior in the field, and appropriated for further laboratory study.
\end{abstract}

The study of animal behavior in psychology is coming increasingly to be focused upon behavioral patterns that constitute parts of the natural behavioral repertoires of various species. Behavioral patterns that are ideal for such analyses are those that are readily elicited without extensive training and that are species-specific and robust with respect to their occurrence under various conditions. Ideally, such behavior should be observable in relatively short tests, so that effects of various factors and manipulations on behavior can be studied efficiently. A first step in the study of such behavior is the development of behavioral norms. Following that, the behavior can be studied from the standpoint of its controlling mechanisms, development, evolutionary history, and adaptive significance.

Digging behavior is ecologically significant in the construction of shelter from environmental extremes, procurement of food, and provision of safe nesting sites (Boice, 1977). The relative importance to members of a particular group of species of a behavior such as digging would be expected to be reflected in the extent to which animals of each species exhibit the behavior under standardized testing conditions (King, Price, \& Weber, 1968). Digging behavior has previously been studied in several species of Peromyscus (King et al., 1968; King \& Weisman, 1964; Layne \& Ehrhart, 1970). The present study complements previous studies by providing additional information on the parameters of digging behavior in the genus Peromyscus and also includes data on members of four other genera (Microtus, Mus, Onychomys, and Rhabdomys). The motor patterns used in diggings are also described.

This research was supported by Grant BNS78-05173 from the National Science Foundation.

\section{METHOD}

The subjects were 118 male muroid rodents from the following 12 taxa: Peromyscus maniculatus blandus and $P . m$. bairdi (deer mice), $P$. eremicus (cactus mice), $P$. gossypinus (cotton mice), $P$. leucopus (white-footed mice), $P$. polionotus (oldfield mice), Microtus montanus (montane voles), $M$. pennsylvanicus (meadow voles), $M$. ochrogaster (prairie voles), Mus musculus (house mice), Onychomys leucogaster (northern grasshopper mice), and Rhabdomys pumilio (African four-striped grass mice). The customary abbreviations for genera will be used; although some genera start with identical letters, species names permit unambiguous identification. These taxa had been maintained in the laboratory for varying numbers of generations. All animals were from $\mathbf{4 0}$ to 60 days of age at the time of testing. The animals were housed in either $48 \times 27 \times 13 \mathrm{~cm}$ or $29 \times 18 \times 13 \mathrm{~cm}$ plastic cages. Wood shavings were provided for bedding. The rooms were maintained on a reversed 16:8 photoperiod. Food and water were provided ad lib.

For observation, the animals were placed in one of two boxes constructed of $1 / 4-$ in. plywood with a Plexiglas front and measuring $61.0 \times 58.0 \times 59.5 \mathrm{~cm}$. All wood surfaces were painted neutral gray, and each box was illuminated by a single $25-\mathrm{W}$ red light bulb suspended through a hole in the lid. Because substrate cues related to a species' ecology may affect the amount of digging displayed by that species (Layne \& Ehrhart, 1970), both sand and peat, to a depth of approximately $5 \mathrm{~cm}$, were used as digging substrates.

With the exception of $P . m$. blandus, 10 animals of each taxon were observed on each substrate; only $8 P . \mathrm{m}$. blandus were tested on peat. Each animal was placed in the digging box on either peat or sand for 10 min on 2 consecutive days. By using 2 days of observation, effects of experience could be assessed. The animals were observed during the early to middle part of the dark phase of their photoperiod.

Three measures were obtained using an Esterline Angus event recorder: the duration of digging, the latency to dig, and the number of bouts of digging. The duration of digging was defined as the amount of time (seconds) from when an animal initiated coordinated digging, using both front and hind legs together, until the animal stopped digging. A bout of digging was scored for each unbroken interval of digging. The latency to dig was defined as the time (seconds) from the introduction of an animal into the digging box until it exhibited coordinated digging (animals that did not dig were assigned a latency of $600 \mathrm{sec}$ ). One derived 
measure, bout length (the mean length, in seconds, of digging bouts), was also analyzed.

Four observers (D.W., M.W., R.O., V.G.) collected data on the digging measures. To increase interobserver reliability, each observer participated in a series of nonexperimental observation sessions with the other observers. To further minimize interobserver differences on comparisons across taxa, at least two different observers collected data on different animals of each taxon for each substrate. A single observer collected data for both days of observation on any particular animal.

Additional animals from each taxon were observed by one of the investigators (D.W.) to determine the exact motor patterns used in digging. At least two male animals, 40 to 150 days of age, were observed from each taxon. Because of the difficulty of observing paw movements on the peat substrate, all animals were observed on sand. A board was provided in the digging box as an additional stimulus to induce digging in some taxa in these tests.

\section{RESULTS}

The mean duration of digging, averaged across all animals in each taxon, is presented in Figure 1. This is the most comprehensive measure of digging in the study. It can be seen that the means ranged from $.3 \mathrm{sec}$ for $P$. gossypinus on sand to $93.6 \mathrm{sec}$ for $P$. polionotus on peat. For 5 of the 12 taxa, the mean duration of digging on both sand and peat was less than $10 \mathrm{sec}$ of the $10 \mathrm{~min}$ allotted. Members of four taxa had means greater than 1 min on peat; none had means of $1 \mathrm{~min}$ or more on sand. Eight of the 12 taxa dug more on peat than on sand.

The data in Figure 1 are a function of both the number of animals digging and the amount of digging behavior by those animals that dug. These data are broken down for analysis in Tables 1 and 2 and Figure 2. The data in Table 1 include all animals; those in Table 2 include only animals that dug. Because some animals dug on both days and others on just one, the mean per day of digging for each animal was used as the basic datum for analysis with respect to digging animals only.

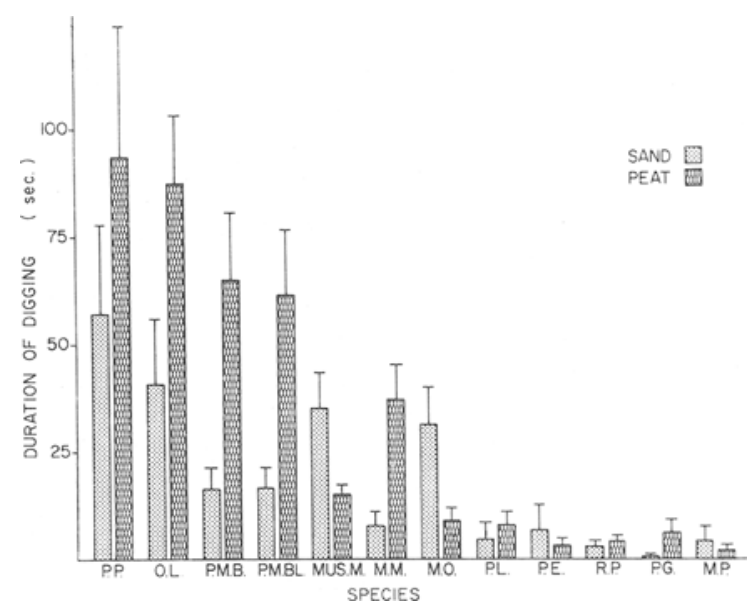

Figure 1. Mean durations of digging for all animals of 12 taxa on sand and pent. Abbreviatlons: PP, Peromyscus polionotus; OL, Onychomys leucogaster; PMB, P. maniculatus bairdi; PMBL, P. m. blandus; MUSM, Mus musculus; MM, Microtus montanus; MO, M. ochrogaster; PL, P. leucopus; PE, P. eremicus; RP, Rhabdomys pumilio; PG, P. gossypinus; MP, M. pennsylvanicus.

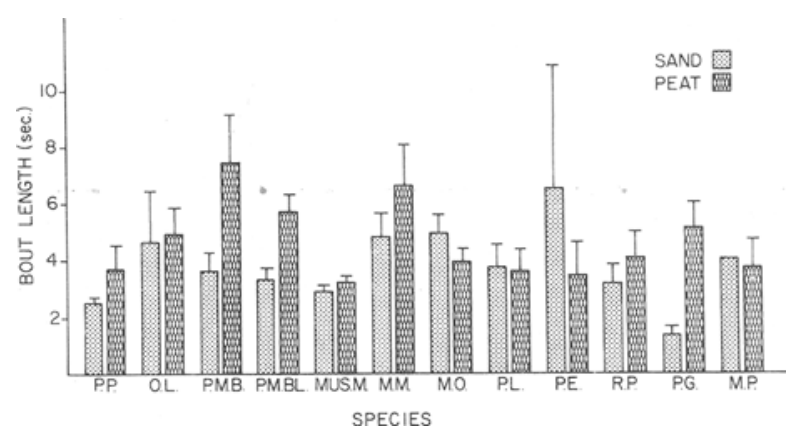

Figure 2. Mean lengths of bouts of digging for all digging animals on peat and sand. For an explanation of abbreviations, see Figure 1.

Table 1

Percentage of Animals Digging and Mean Scores on Each Substrate

\begin{tabular}{|c|c|c|c|c|c|c|c|c|c|c|}
\hline & & & \multicolumn{4}{|c|}{ Number of Bouts } & \multicolumn{4}{|c|}{ Latency (in Seconds) } \\
\hline & \multicolumn{2}{|c|}{ Percent Digging } & \multicolumn{2}{|c|}{ Sand } & \multicolumn{2}{|c|}{ Peat } & \multicolumn{2}{|c|}{ Sand } & \multicolumn{2}{|c|}{ Peat } \\
\hline & Sand & Peat & Mean & $\mathrm{SE}$ & Mean & $\mathrm{SE}$ & Mean & $\mathrm{SE}$ & Mean & $\mathrm{SE}$ \\
\hline PP & 100 & 90 & 20.0 & 5.5 & 21.0 & 4.7 & 224.5 & 46.0 & 170.6 & 58.2 \\
\hline OL & 100 & 100 & 9.5 & 1.1 & 18.3 & 1.6 & 167.6 & 37.1 & 54.7 & 10.8 \\
\hline PMB & 80 & 100 & 4.9 & 1.6 & 11.0 & 2.1 & 286.3 & 66.5 & 247.1 & 55.7 \\
\hline PMBL & 90 & 100 & 4.7 & 1.2 & 10.6 & 1.8 & 314.8 & 50.6 & 208.1 & 47.4 \\
\hline MUSM & 100 & 100 & 11.4 & 2.6 & 5.1 & $\begin{array}{r}.0 \\
.7\end{array}$ & 250.9 & 47.2 & 343.4 & 21.0 \\
\hline MM & 60 & 80 & 1.8 & .7 & 6.2 & 1.7 & 414.0 & 67.0 & 285.4 & 69.6 \\
\hline MO & 100 & 80 & 5.9 & 1.2 & 2.2 & .7 & 216.4 & 22.8 & 349.4 & 56.1 \\
\hline PL & 40 & 60 & 1.2 & .8 & 2.5 & 1.1 & 497.4 & 56.4 & 398.1 & 67.1 \\
\hline $\mathrm{PE}$ & 20 & 30 & .8 & .6 & .9 & .5 & 575.6 & 17.4 & 533.2 & 41.2 \\
\hline RP & 40 & 50 & .9 & .4 & 1.1 & .4 & 541.0 & 27.2 & 485.3 & 44.7 \\
\hline PG & 20 & 40 & .2 & .2 & 1.2 & .5 & 593.1 & 5.7 & 485.7 & 50.4 \\
\hline MP & 10 & 30 & 1.0 & 1.0 & .5 & .3 & 586.5 & 13.5 & 564.5 & 22.1 \\
\hline
\end{tabular}

Note-For explanation of abbreviations, see Figure 1. 
Table 2

Mean Taxon Scores Based on Digging Animals Only

\begin{tabular}{|c|c|c|c|c|c|c|c|c|c|c|c|c|}
\hline & \multicolumn{4}{|c|}{ Duration (in Seconds) } & \multicolumn{4}{|c|}{ Number of Bouts } & \multicolumn{4}{|c|}{ Latency (in Seconds) } \\
\hline & \multicolumn{2}{|c|}{ Sand } & \multicolumn{2}{|c|}{ Peat } & \multicolumn{2}{|c|}{ Sand } & \multicolumn{2}{|c|}{ Peat } & \multicolumn{2}{|c|}{ Sand } & \multicolumn{2}{|c|}{ Peat } \\
\hline & Mean & SE & Mean & $\mathrm{SE}$ & Mean & SE & Mean & $\mathrm{SE}$ & Mean & $\mathrm{SE}$ & Mean & $\mathrm{SE}$ \\
\hline PP & 61.6 & 20.0 & 104.6 & 31.5 & 22.0 & 5.0 & 27.3 & 4.3 & 138.0 & 22.8 & 99.6 & 19.1 \\
\hline $\mathrm{OL}$ & 40.9 & 14.7 & 87.4 & 15.8 & 9.5 & 1.1 & 18.3 & 1.6 & 167.6 & 37.1 & 54.7 & 10.8 \\
\hline PMB & 21.4 & 5.3 & 66.6 & 15.1 & 6.4 & 1.6 & 11.2 & 2.1 & 162.6 & 30.1 & 227.5 & 37.7 \\
\hline PMBL & 23.6 & 7.1 & 63.1 & 14.6 & 6.6 & 1.7 & 10.9 & 1.6 & 173.2 & 44.4 & 195.3 & 36.8 \\
\hline MUSM & 36.4 & 7.8 & 16.3 & 2.2 & 12.0 & 2.4 & 5.1 & .7 & 227.9 & 35.6 & 343.4 & 21.0 \\
\hline MM & 13.3 & 3.2 & 51.7 & 9.9 & 3.0 & .8 & 8.3 & 1.6 & 281.3 & 70.5 & 162.4 & 39.1 \\
\hline MO & 31.1 & 8.7 & 11.6 & 3.4 & 5.9 & 1.2 & 2.9 & .8 & 216.4 & 22.8 & 246.8 & 36.2 \\
\hline PL & 13.0 & 8.7 & 16.8 & 4.0 & 3.1 & 1.7 & 5.5 & 1.3 & 304.1 & 83.4 & 107.8 & 31.9 \\
\hline $\mathrm{PE}$ & 34.3 & 25.3 & 11.0 & 5.2 & 4.8 & .8 & 3.0 & 1.0 & 437.8 & 1.3 & 354.5 & 71.5 \\
\hline $\mathrm{RP}$ & 13.5 & 2.9 & 11.1 & 2.3 & 4.3 & .3 & 2.8 & .5 & 305.0 & 69.7 & 315.3 & 34.8 \\
\hline PG & 3.0 & 2.0 & 20.3 & 7.6 & 2.0 & 1.0 & 3.8 & 1.2 & 531.0 & 45.0 & 281.5 & 19.2 \\
\hline MP & 39.0 & .0 & 12.7 & 7.2 & 10.0 & .0 & 3.0 & 1.0 & 465.0 & .0 & 363.3 & 99.0 \\
\hline
\end{tabular}

Note-For abbreviations, see Figure 1.

Table 3

Results of Analyses of Variance of Data on Digging in 12 Species of Muroid Rodents

\begin{tabular}{|c|c|c|c|c|c|}
\hline Measure & Days & Among Taxa & Substrate & Taxa on Sand & Taxa on Peat \\
\hline & \multicolumn{5}{|c|}{ All Animals } \\
\hline $\begin{array}{l}\text { Duration of Digging } \\
\text { Number of Bouts of Digging } \\
\text { Latency to Dig }\end{array}$ & $\begin{array}{c}4.63^{*} \\
.54 \\
.68\end{array}$ & $\begin{array}{l}11.07 \dagger \\
21.84 \dagger \\
22.79 \dagger\end{array}$ & $\begin{array}{l}6.49^{*} \\
1.82 \\
2.57\end{array}$ & $\begin{array}{r}4.33 \dagger \\
9.17 \dagger \\
14.38 \dagger\end{array}$ & $\begin{array}{r}8.36 \dagger \\
15.91 \dagger \\
10.40 \dagger\end{array}$ \\
\hline Latency to Dig & \multicolumn{5}{|c|}{ Digging Animals Only } \\
\hline $\begin{array}{l}\text { Duration of Digging } \\
\text { Number of Bouts of Digging } \\
\text { Latency to Dig }\end{array}$ & & $\begin{array}{r}4.00 \dagger \\
10.63 \dagger \\
7.20 \dagger\end{array}$ & $\begin{array}{c}4.91^{*} \\
.36 \\
.42\end{array}$ & $\begin{array}{l}1.37 \\
4.27 \dagger \\
4.04 \dagger\end{array}$ & $\begin{array}{c}4.56 \dagger \\
10.57 \dagger \\
8.21^{* *}\end{array}$ \\
\hline
\end{tabular}

${ }^{*} p<.05 . \quad * * p<.01 . \quad \dagger p<.001$.

All $O$. leucogaster and $M$. musculus dug on both substrates; only $10 \%$ of $M$. pennsylvanicus dug on sand and $30 \%$ on peat. Differences across taxa in the number of animals that dug on sand were significant $\left[\chi^{2}=22.2, p<.05\right]$, whereas the comparable difference on peat was not significant $\left[\chi^{2}=12.2\right.$, $p>$ $.05]$. There was no significant difference between the number of animals digging on sand vs. peat (sign test, $\mathrm{p}>.05$ ).

The statistical significance of various factors potentially affecting the duration of digging, the number of bouts of digging, and the latency to dig both for all animals and for digging animals only were analyzed with analyses of variance. The results are presented in Table 3. When analyzed for all animals, highly significant differences were found across taxa for the duration of digging, the number of bouts, and the latency to dig on both peat and sand. The only significant effect of substrate was on the duration of digging, with animals doing more digging overall on peat than on sand. The only significant change between days was in the duration of digging; although the pattern of the data lacked consistency across taxa, there was more digging overall on Day 2 than on Day 1. The mean digging durations per species on sand for Days 1 and 2 were 179.8 and $191.3 \mathrm{sec}$, respectively. The durations on peat were $291.2 \mathrm{sec}$ for Day 1 and 342.6 sec for Day 2. When only digging animals were included in the analysis, results were similar to those obtained for all animals, except that taxa did not differ significantly with respect to the duration of digging on sand.

When data on bout lengths were analyzed, it was found that the mean bout length on peat was significantly longer than that on sand $[F(1,158)=5.12$, $\mathrm{p}<.05]$. However, bout lengths did not differ significantly across taxa on either sand or peat.

Correlations among digging measures are presented in Table 4. The percentage of animals of each taxon that dug was positively correlated with both the duration of digging and the number of bouts of digging, and negatively correlated with the latency to dig on both substrates, whether data from all animals or from only digging animals were used. Correlations tended to be smaller when only scores from digging animals were used. With data from all 
Table 4

Correlations Among Digging Measures for 12 Taxa of Muroid Rodents

\begin{tabular}{|c|c|c|c|c|c|c|c|c|}
\hline \multirow[b]{2}{*}{ Measure } & \multicolumn{4}{|c|}{ Sand } & \multicolumn{4}{|c|}{ Peat } \\
\hline & Duration & $\begin{array}{l}\text { Number } \\
\text { of Bouts }\end{array}$ & Latency & $\begin{array}{c}\text { Bout } \\
\text { Length }\end{array}$ & Duration & $\begin{array}{l}\text { Number } \\
\text { of Bouts }\end{array}$ & Latency & $\begin{array}{c}\text { Bout } \\
\text { Length }\end{array}$ \\
\hline & \multicolumn{8}{|c|}{ All Animals } \\
\hline \multirow[t]{2}{*}{$\begin{array}{l}\text { Percent Digging } \\
\text { Duration of Digging } \\
\text { Number of Bouts of Digging }\end{array}$} & $.81 \dagger$ & $\begin{array}{l}.81 \dagger \\
.85 \dagger\end{array}$ & $\begin{array}{r}-.87 \dagger \\
.63 \dagger \\
-.66 \dagger\end{array}$ & & $.74 \dagger$ & $\begin{array}{l}.71 \dagger \\
.86 \dagger\end{array}$ & $\begin{array}{l}-.81 \dagger \\
-.67 \dagger \\
-.76 \dagger\end{array}$ & \\
\hline & \multicolumn{8}{|c|}{ Digging Animals Only } \\
\hline $\begin{array}{l}\text { Percent Digging } \\
\text { Duration of Digging } \\
\text { Number of Bouts of Digging } \\
\text { Latency to Dig }\end{array}$ & $.42 *$ & $\begin{array}{l}.42^{*} \\
.80 \dagger\end{array}$ & $\begin{array}{l}-.71 \dagger \\
-.40 \dagger \\
-.45 \dagger\end{array}$ & $\begin{array}{c}-.10 \\
.45 \dagger \\
.10 \\
-.05\end{array}$ & $.52 *$ & $\begin{array}{l}.52 * \\
.82 \dagger\end{array}$ & $\begin{array}{l}-.45^{*} \\
-.52 \dagger \\
-.61 \dagger\end{array}$ & $\begin{array}{l}.21 \\
.37 \dagger \\
.01 \\
.04\end{array}$ \\
\hline
\end{tabular}

Note-Correlations with percent digging were performed using Kendall correlations; all other analyses were performed using partial correlation procedures. ${ }^{*} p<.05 . \quad t_{p}<.001$.

animals, or from digging animals, the duration of digging and the number of bouts of digging were found both to be positively correlated with each other and negatively correlated with the latency to dig on each substrate. Bout length was found to be positively correlated with digging duration for both sand $(r=.45, p<.001)$ and peat $(r=.37, p<.001)$.

A summary of the motor patterns used in digging by the animals in this study and those of other studies is presented in Table 5. These are the first descriptions available for $P$. leucopus, $M$. montanus, $M$. pennsylvanicus, $M$. ochrogaster, and $M$. musculus. $P$. $\boldsymbol{m}$. blandus were not available when the observations were made. The most prevalent pattern in the present study involved simultaneous use of the rear paws together with alternating use of the forepaws. Only $M$. musculus and $R$. pumilio displayed alternating patterns with the rear paws. Although, in the present study, $O$. leucogaster was the only species to exhibit more than one pattern, other investigators

Table 5

Digging Patterns Displayed by Various Taxa

\begin{tabular}{|c|c|}
\hline Alternating Rear Paws & Simultaneous Rear Paws \\
\hline \multicolumn{2}{|c|}{ Alternating Forepaws } \\
\hline M. musculus & $\begin{array}{l}\text { P. gossypinus } \\
\text { P. leucopus } \\
\text { P. polionotus } \\
\text { P. eremicus } \\
\text { M. montanus } \\
\text { M. pennsylvanicus } \\
\text { M. ochrogaster } \\
\text { O. leucogaster }\end{array}$ \\
\hline \multicolumn{2}{|c|}{ Simultaneous Forepaws } \\
\hline R. pumilio & $\begin{array}{l}\text { P. m. bairdi } \\
\text { O. leucogaster }\end{array}$ \\
\hline $\begin{array}{l}\text { O. leucogaster }{ }^{*} \\
P . \text { gossypinus } t \\
P . \text { floridanus }{ }^{\dagger} \\
P . \text { polionotus } f\end{array}$ & $\begin{array}{l}\text { P. gossypinust } \\
\text { P. floridanust } \\
P . \text { polionotus } t\end{array}$ \\
\hline
\end{tabular}

*Ruffer (1965). Tlayne and Ehrhart (1970). have noted additional patterns for several species. $M$. musculus is the only species that has been observed to exhibit alternating fore- and rear paws. Animals of all species except $O$. leucogaster always initiated digging with the forepaws; $O$. leucogaster occasionally initiated the simultaneous forepaw and rear-paw pattern with the rear paws. Layne and Ehrhart (1970) have described $P$. gossypinus as also occasionally initiating digging with the rear paws.

\section{DISCUSSION}

There were large differences among taxa in the amount of digging on each substrate. Overall, there was more digging in peat than in sand. Interpretation of these observations and comparison of the present data with those from previous studies can be made in light of various factors that may have influenced the scores obtained.

The present data can be compared with the earlier data of Layne and Ehrhart (1970) because there were three species common to both studies $(P$. gossypinus, $P$. leucopus, and $P$. polionotus). The two studies were very similar with respect to procedural details such as the size of the boxes, depth and type of substrate, animal housing conditions, and test duration. Although many of the results were quite similar, animals in the present study differed in that they had longer latencies to dig, dug less, and dug more on peat than on sand. In the present study, 2 test days were used rather than one and a more restrictive definition of digging was adopted; neither factor appears to explain the differences observed. The textures of the substrates used differed between studies and may have been one relevant factor. Also, Layne and Ehrhart tested animals in white, rather than red, light. This may have increased rates of digging as animals move to escape the more aversive situation.

There are some differences between the motor patterns observed in the present study and those de- 
scribed by previous workers (e.g., Layne \& Ehrhart, 1970; Ruffer, 1965). For example, while $P$. gossypinus and $P$. polionotus exhibited patterns with alternating forepaw and simultaneous rear-paw movement in the present study, they have previously been reported to use a pattern with simultaneous forepaw and either alternating or simultaneous rear-paw movement. It is unlikely that these differences are attributable to laboratory rearing (see Dawson \& Lake, 1974; Layne \& Ehrhart, 1970). The differences may reflect genetically based tendencies for the use of particular patterns by different local populations of the same species (e.g., Wolfe \& Esher, 1977).

Taxa exhibited fairly restricted ranges of mean bout lengths, even though scores for average digging durations varied widely. This may indicate selection for optimal lengths of digging bouts. Perhaps a balance has been reached between pressures for longer bout lengths to complete burrows rapidly and for shorter bout lengths that may allow better avoidance of predators.

As suggested by Layne and Ehrhart, differences in the overall duration of digging appear to be correlated with the nesting habits of different taxa. The substantial burrows of $P$. polionotus have been described by various authors (e.g., Hayne, 1936; Smith, 1966), and Ruffer (1965) has described the burrowing behavior of $O$. leucogaster. $P$. maniculatus are also known to burrow (Burt \& Grossenheider, 1976), and Berry (1968) has described extensive burrow systems in feral populations of $M$. musculus on Skokholm island. The next most vigorous diggers after these five taxa were $M$. ochrogaster, which "makes a tortuous network of paths through the grass and honeycombs the topsoil with its tunnels" (Jameson, 1947), and M. montanus, which has been described by Maser and Storm (1970) as utilizing winter nests above ground and subterranean summer nests. Three of the remaining five species, $P$. leucopus, $P$. eremicus, and $P$. gossypinus, are all semi-arboreal species and, from descriptions of their nesting habits, would not be expected to burrow as much as others. $M$. pennsylvanicus may construct its nests from vegetation above ground (Maser \& Storm, 1970), although they have also been described (Doutt, Heppenstall, \& Guilday, 1967) as making burrows along their surface runways. Although $R$. pumilio have been observed to burrow in the field (Shortridge, 1934), they are regarded as a species that is not primarily burrowing (Nel, 1975).

Although many species showed different amounts of digging on the two substrates, these differences do not appear to be correlated with ecological dif- ferences. $P$. polionotus, for example, is typically found on sandy substrates, and $O$. leucogaster is often found on sandy soil (Burt \& Grossenheider, 1976). However, both of these species dug more on peat than on sand. Textural cues associated with the substrates may be important.

Digging behavior can be seen to be species-typical, robust in the laboratory, and related to behavioral habits displayed in the field. It is an appropriate behavioral pattern for further analyses of its development, controlling mechanisms, evolutionary history, and adaptive significance.

\section{REFERENCES}

BERRY, R. J. The ecology of an island population of the house mouse. Journal of Animal Ecology, 1968, 37, 445-470.

Borce, R. Burrows of wild and albino rats: Effects of domestication, outdoor raising, age, experience, and maternal state. Journal of Comparative and Physiological Psychology, 1977, 91, 649-661.

Burt, W. H., \& Grossenheiden, R. P. A field guide to the mammals. Boston: Houghton Mifflin, 1976.

Dawson, W. D., \& LAKE, C. Inheritance of burrow building in Peromyscus. ASB Bulletin, 1974, 21, 50.

Doutt, J. K., Heppenstal., C. A., \& Guilday, J. E. Mammals of Pennsylvania. Harrisburg: Pennsylvania Game Commission, 1967.

Hayne, D. W. Burrowing habits of Peromyscus polionotus. Journal of Mammalogy, 1936, 17, 420-421.

Jameson, E. W., JR. Natural history of the prairie vole (Mammalian genus Microtus). University of Kansas Publications, Museum of Natural History, 1947, 1, 125-151.

King, J. A., Price, E. O., \& Weber, P. L. Behavioral comparisons within the genus Peromyscus. Papers of the Michigan Academy of Science, Arts and Letters, 1968, 53, 113-136.

KING, J. A., \& Weisman, R. G. Sand digging contingent upon bar pressing in deer mice (Peromyscus). Animal Behaviour, $1964,12,446-450$.

Layne, J. N., \& Ehrhart, L. M. Digging behavior of four species of deer mice (Peromyscus). American Museum Novitiates, 1970, 2429, 1-16.

Masen, C., \& Storm, R. M. A key to Microtinae of the Pacific Northwest. Corvallis, Oreg: O.S.U. Bookstores, 1970.

NEL, J. A. J. Aspects of the social ethology of some Kalahari rodents. Zeitschrift fur Tierpsychologie, 1975, 37, 322-331.

Ruffer, D. G. Burrows and burrowing behavior of Onychomys leucogaster. Journal of Mammalogy, 1965, 46, 241-247.

Shontridge, G. C. The mammals of south west Africa. London: William Heinemann, 1934.

Sмгтн, M. H. The evolutionary significance of certain behavioral, physiological and morphological adaptations of the old-field mouse (Peromyscus polionotus). Unpublished doctoral dissertation, University of Florida, 1966.

WolfE, J. L., \& Esher, R. J. Burrowing behavior of old-field mice (Peromyscus polionotus): A laboratory investigation. Biology of Behavior, 1977, 2, 343-351.

(Received for publication September 2, 1980; revision accepted January 12,1981 .) 